\title{
STRUKTURA NADZEMNE BIOMASE DIVLJE TREŠNJE (PRUNUS AVIUM L.) U NIZINSKIM ŠUMAMA HRVATSKE
}

\section{THE STRUCTURE OF ABOVE-GROUND BIOMASS OF WILD CHERRY (Prunus avium L.) IN LOWLAND CROATIAN FORESTS}

'Željko ZEČIĆ, 'Andreja ĐUKA, 'Dinko VUSIĆ, 'Branko URSIĆ, 'Davor BENIĆ

\begin{abstract}
SAŽETAK
U radu su prikazane sastavnice strukture ukupne nadzemne biomase stabala divlje trešnje (Prunus avium L.) na području spačvanskog bazena u Upravi šuma Podružnica Vinkovci. Istraživanja su obavljena na 120 primjernih stabala divlje trešnje, prsnih promjera od 10 do $72 \mathrm{~cm}$ i visine od 10,8 do $34,4 \mathrm{~m}$. Drvni sortimenti izrađeni su prema Hrvatskim normama proizvoda iskorištavanja šuma iz 1995. godine.

Sortimentna struktura primjernih stabala divlje trešnje pokazuje znatna odstupanja u odnosu na tablice sortimentne strukture za voćkarice koje koristi trgovačko društvo „Hrvatske šume“ d.o.o. Zagreb. Udio trupaca za furnir kreće se od 9,29 \% u debljinskom stupnju 37,5 cm do najviše $19,50 \%$ u debljinskom stupnju $67,5 \mathrm{~cm}$. Pilanski trupci prvog razreda kakvoće kreću se u rasponu od 12,04 \% $(72,5 \mathrm{~cm})$ do $19,89 \%(32,5 \mathrm{~cm})$, a drugog razreda kakvoće od 17,30 \% (62,5 cm) do 26,89\% (32,5 cm). Drvni sortiment tanke oblovine zastupljen je u debljinskom stupnju $17,5 \mathrm{~cm}$ sa $17,44 \%$ te u debljinskom stupnju $22,5 \mathrm{~cm}$ sa $15,90 \%$, dok je u višim debljinskim stupnjevima značajno manje zastupljen. Udio prostornog drva je najveći u prvom debljinskom stupnju 88,76 \% $(12,5 \mathrm{~cm})$ te u sljedeća dva sa $67,44 \%$ i $47,71 \%$, a najmanji je u debljinskom stupnju $67,5 \mathrm{~cm}$ sa $27,01 \%$. Prosječni udio prostornoga drva iznosi $42,09 \%$. Otpad se u ukupnoj strukturi krupnog drva kreće od $11,24 \%(12,5 \mathrm{~cm})$ do $19,12 \%(27,5 \mathrm{~cm})$, a prosječno iznosi $16,47 \%$. Dvostruka debljina kore kreće se u rasponu od $0,53 \mathrm{~cm}$ do $3,37 \mathrm{~cm}$, odnosno prosječno $1,66 \pm 0,57 \mathrm{~cm}$, a postotni udio kore kreće se od 4,77 \% do $16,46 \%$, sa srednjom vrijednošću od $9,02 \pm 2,01 \%$.
\end{abstract}

Utvrđeni su i parametri Schumacher-Hallove jednadžbe, gustoća drva, udio vode, obujam granjevine (promjera $<7 \mathrm{~cm}$ ) te struktura ukupne nadzemne biomase.

KLJUČNE RIJEČl: drvni obujam, drvni sortimenti, debljina kore, otpad

\section{UVOD}

\section{INTRODUCTION}

Istraživanja nadzemne biomase stabla, pod kojom se podrazumijeva cjelokupni drvni obujam stabla, od razine tla do vršnoga pupa, nametnuli su aktualni trendovi u njenom korištenju, jer su uvođenjem novih tehnologija svi dijelovi stabla postali iskoristivi. Oni dijelovi stabla, koji su nakon sječe, izrade i izvoženja, ostajali u šumi kao otpad ili granjevina, postali su vrlo tražen energent. Razlozi leže u činjenici kako je ljudska potreba za svim oblicima energije i

\footnotetext{
1 Prof. dr. sc. Željko Zečić, Sveučilište u Zagrebu, Fakultet šumarstva i drvne tehnologije, Zavod za šumarske tehnike i tehnologije, Svetošimunska cesta 23, 10000 Zagreb, Republika Hrvatska, e-mail: zzecic@sumfak.unizg.hr

${ }^{1}$ Doc. dr. sc. Andreja Đuka, e-mail: aduka@sumfak.unizg.hr

1 Doc. dr. sc. Dinko Vusić, e-mail: dvusic@sumfak.unizg.hr

Branko Ursić, mag. ing. silv., e-mail: bursic@sumfak.unizg.hr

${ }^{2}$ univ. spec. silv. Davor Benić, Hrvatske šume Zagreb, UŠP Vinkovci, Trg bana Josipa Šokčevića 20, 32100 Vinkovci, Republika Hrvatska, e-mail: davor.benic@hrsume.hr
} 
proizvoda sve veća, uz istodobno shvaćanje kako su nam resursi ograničeni. Uz to se nadovezuje napredak tehničkih sredstava i tehnoloških procesa koji nam omogućuju lakšu i učinkovitiju proizvodnju, ali zahtijevaju standarde pomnijeg planiranja. Upotrebljivost i operativnost donesenih poslovnih odluka nije moguća bez poznavanja sortimentne strukture planiranog etata.

Zbog točnog i stručnog planiranja izvođenja radova prije sječe i izrade te analiza nakon sječe, postoji potreba za utvrđivanjem drvnog obujma stabala predviđenih za sječu, kao i sortimentne strukture stabala, odnosno sječine. Kvalitetna izrada plana sječa nije moguća bez odgovarajućih sortimentnih tablica. Izrada sortimentnih tablica predstavlja vremenski dugotrajan posao koji se sastoji od terenskog prikupljanja podataka, te njihove obrade koja rezultira izradom matematičko-statističkih modela. Sve dosadašnje metode utvrđivanja sortimentne strukture zahtijevaju da se primjernim stablima odredi ukupni obujam i obujam sortimenata u dubećem ili oborenom stanju, što zahtijeva utrošak znatne količine vremena (Pranjić i Lukić 1997). Uz zahtjevan postupak izrade velik nedostatak sortimentnih tablica je to što one u pravilu vrijede za ona područja za koja su izrađene, jer promjena stanišnih uvjeta donosi promjene značajki pada promjera i debljine kore. Također, s vremenom se mogu promijeniti prirodni ili ekonomski uvjeti koji mogu utjecati na točnost ili upotrebljivost tablica (Perković 2010).

Trgovačko društvo „Hrvatske šume“ d.o.o. Zagreb pri planiranju primjenjuje jedinstvene tablice udjela drvnih sortimenata za voćkarice, jer do sada u Hrvatskoj nisu napravljena istraživanja sortimentne strukture pojedinih vrsta voćkarica, pa tako ni za divlju trešnju. Nedovoljno poznavanje strukture nadzemne biomase, posebice udjela tehničke oblovine, rezultira izradom nepotpunih planova sječa. Stoga se najčešće u odnosu na plan ostvaruje kvalitetnija sortimentna struktura, kao i veće izvršenje ukupnog drvnog obujma od planiranog. Kako bi se što bolje planiralo poslovanje, neophodno je znati količinu, kakvoću i ekonomsku vrijednost obujma drva koji će se u idućem razdoblju posjeći i izraditi.

U Hrvatskoj se primjenjuju Hrvatske norme proizvoda iskorištavanja šuma (1995), a osnovna im je značajka klasifikacija drvnih sortimenta prema namjeni, dok je kod novih europskih, odnosno hrvatskih normi (HRN EN) namjena drvnih sortimenata prepuštena tržišnim odnosima, a klasifikacija se obavlja prema kakvoći. Za divlju trešnju u Hrvatskoj nije tiskana europska norma.

Divlja trešnja spada u vrste drveća s tankom korom koja je sive boje, ljušti se u horizontalnim prstenastim trakama. U starosti se javlja i ispucala mrtva kora. Debljina kore pojedinog stabla ovisi o promjeru stabla, ekološkim prilikama u kojima se stablo razvijalo i raslo i položaju koje stablo zauzima u sastojini. Neka istraživanja utvrdila su opće pri- hvaćene zakonitosti ponašanja kore na stablima (Krpan 1986). Dvostruka debljina kore stabla opada od panja prema vrhu, a povećava se s povećanjem promjera obloga drva. Postotni udio kore se smanjuje povećanjem promjera, a povećava se smanjenjem promjera.

Divlja trešnja je najzastupljenija voćkarica u Republici Hrvatskoj, ali s relativno malim udjelom u ukupnoj drvnoj zalihi, gdje je zasebno iskazana s tek $0,28 \%$ odnosno $1.189 .789 \mathrm{~m}^{3}$ (ŠGOP RH 2016) dok je određeni udio iskazan i u kategoriji ostale tvrde bjelogorice (OTB). Njen potencijal je zasigurno višestruko veći i u zadnje vrijeme naglašen je kroz osnivanje sjemenskih klonskih plantaža divlje trešnje (šumarija Kutina) i istraživanja njenih šumsko-uzgojnih svojstava te mogućnosti proizvodnje sadnica (Pavelić 2006). Divlja trešnja zauzima poziciju vrste kojoj treba posvetiti veću pozornost kako u uzgojnom, tako i u smislu pridobivanja drva, odnosno povećanju prihoda.

Dosadašnja istraživanja koja se odnose na problematiku poznavanja količine i kakvoće nadzemne biomase možemo podijeliti na istraživanja vezana uz produkciju biomase, utvrđivanje strukture drvnih sortimenata u iskorištenom obujmu (etatu) i čimbenicima koji utječu na količinu i kakvoću proizvedene drvne tvari. Tako Perić (2001) mjeri produkciju drvnog obujma različitih provenijencija hrasta lužnjaka na dva različita lokaliteta, jednog na području srednje, a drugog na području istočne Hrvatske.

Krpan i drugi (2011) istražuju cjelokupnu strukturu nadzemne biomase stabala alepskog bora, kao naše autohtone vrste $s$ velikim potencijalom za proizvodnju biomase za energiju na priobalnom području. Obavlja se sječa i izrada modelnih stabala i utvrđuje se kakvoćna struktura izrađenih drvnih sortimenata, mjeri se sitna granjevina, češeri i posebno iglice. Komlenović i dr. (1996) uz nadzemnu istražuju i podzemnu biomasu u klonskom testu stablastih vrba na području šumarije Čakovec. Utvrđuju i sadržaj suhe tvari uzoraka biljnog materijala gravimetrijskom metodom. Lukić i Kružić (1996) izrađuju regresijske modele biomase deblovine za običnu bukvu, za bukove jednodobne sastojine i regresijski model totalne težine biomase za običnu bukvu. Obrađena su srednja plošna sastojinska stabla kako bi se obuhvatili svi dobni i bonitetni razredi. Bogdan i dr. (2006) u šumarijama Darda i Čazma istražuju potencijal proizvodnje biomase stablastih vrba na marginalnim tlima koja nisu prikladna za uzgajanje ekonomski vrjednijih vrsta drveća. Zečić i dr. (2011) istražuju ukupnu nadzemnu biomasu stabala obične jele, europskog ariša i crnog bora u prirodnim šumama i šumskim kulturama. Vusić i dr. (2019) istražuju prinos biomase različitih klonova topole s naglaskom na značajke koje određuju prikladnost uporabe proizvedene biomase u energijske svrhe.

Prka i Krpan (2007) pokušavaju riješiti najveći problem sortimentnih tablica najzastupljenije vrste u Republici Hr- 
vatskoj - obične bukve; njihovu jednoobraznost koja ne uvažava vrstu sijeka kao jedan od ulaza. Dosadašnji pristup univerzalnih tablica udjela šumskih drvnih sortimenata jedne vrste drveća u šumarstvu pokazao se prilično neprikladnim, jer struktura sortimenata kod obične bukve znatno odstupa u ovisnosti o vrsti sijeka. Stoga i usporedba strukture tehničke oblovine bukovih sječina izrađenih prema zahtjevima međunarodnih normi i normi koje se primjenjuju u hrvatskom šumarstvu trebaju posebno uvažavati strukturu izrađenih drvnih sortimenata proreda i pripremnog sijeka, a posebno naplodnog i dovršnog sijeka (Prka i Poršinsky 2009). Krpan i dr. (2006) te Prka i dr. (2009) istražuju pojavu i značajke neprave srži bukovih stabala kao jednog od bitnih čimbenika koji utječe na kakvoću tehničke oblovine, a time na iskorištenje i vrijednost drvnih sortimenata po svim razredima kakvoće, otežavajući ispravno planiranje sortimentne strukture budućih sječina. Pojavnost neprave srži i truleži na bukovoj oblovini istražuju i Arač i dr. (2021) i zaključuju da navedene greške utječu na smanjenje iskorištenja obujma i vrijednosti stabala. Marenče i dr. (2020) donose rezultate monitoringa kakvoće i količine bukova drva od stabla preko drvnog sortimenta do pilanskog proizvoda. Zelić (2004) izrađuje preliminarne sortimentne tablice krupnog drva hrasta sladuna, vrste za koju u šumarskoj operativi takve tablice do tada nisu postojale, utvrdivši kako na strukturu udjela drvnih sortimenata u obujmu stabla i sastojine znatno utječe i bonitet staništa.

Štefančić (1997, 1998) istražuje udjele drvnih sortimenata u obujmu krupnog drva za hrastove lužnjak i kitnjak, poljski jasen i bukvu i pokušava odrediti utjecaj prsnog promjera (debljinskog stupnja) i tarifnog niza (visine stabla) na njihovu pojavnost. Šušnjar (2001) izrađuje sortimentne tablice obične jele za gospodarsku jedinicu „Belevine“ $u$ sklopu Nastavno pokusnog šumskog objekta Zalesina i utvrđuje manje razlike u odnosu na primjenjivane sortimentne tablice.

Zečić i dr. (2009) istražuju sortimentnu strukturu posušenih stabala obične jele, a Tikvić i dr. (2009) istražuju sortimentnu strukturu oštećenih stabala hrasta lužnjaka u spačvanskim šumama. Zečić i dr. (2012) istražuju potencijal biomase obične bukve. Proizvodni potencijal biomase crnoga bora istražuju Zečić i dr. (2013).

Poršinsky i Vujeva (2007) na primjeru smrekove oblovine utvrđuju gubitke obujma drva koji nastaju izmjerom na propisani način. Definiraju gubitke koji nastaju zbog propisanog izraza za izračun obujma, propisanog načina izmjere promjera, odbijanja dvostruke debljine kore i propisanog načina izmjere duljine i ukazuju na nedostatke trenutnih načina izmjere. Time zahvaćaju jednu širu i poznatu problematiku koja izravno utječe na izradu sortimentnih tablica, jer možebitna promjena propisanog načina iz- mjere može dovesti i do potrebe korekcije postojećih sortimentnih tablica. Utjecaj propisanog načina izmjere te načina odbitka dvostruke debljine kore na gubitke obujma drva kod tehničke oblovine hrasta kitnjaka istražuju Đuka i dr. (2020).

Debljinu kore, koja je jedna od bitnih sastavnica otpada pri mjerenju drvnog obujma, istražuju Božić i dr. (2007) na primjeru stabala obične jele. Poršinsky i dr. (2020) istražuju značajke kore divlje trešnje (Prunus avium L.) s obzirom na: 1) dvostruku debljinu u ovisnosti o promjeru izrađene oblovine, 2) udjel kore u ovisnosti o promjeru izrađene oblovine te zaključuju kako se istraživanjem ovisnosti dvostruke debljine kore o promjeru obloga drva s korom komercijalnih vrsta drva, osigurava nepristranost između kupaca i prodavatelja pri trgovini drvom.

Cilj ovoga istraživanja je utvrditi strukturu nadzemne biomase stabala divlje trešnje na području spačvanskih šuma; odnosno:

- odrediti parametre Schumacher-Hallove jednadžbe;

- utvrditi dvostruku debljinu kore, obujam kore i ovisnost debljine kore o srednjem promjeru drvnog sortimenta;

- utvrditi količinu i značajke granjevine (promjera $<7 \mathrm{~cm}$ ) te iskazati količinu granjevine u ukupnoj količini nadzemne biomase stabla i

- konstruirati sortimentne tablice.

\section{MATERIJAL I METODE MATERIAL AND METHODS}

\subsection{Mjesto istraživanja - Research area}

Divlja trešnja je vrsta koja na području spačvanskih šuma pridolazi u pojedinačnom, pratećem obliku u šumskim sastojinama uz hrast lužnjak i poljski jasen. Radi relativno malog broja doznačenih stabala (jer se $s$ divljom trešnjom gospodari na svojevrstan „stablimičan način“) planirano je obaviti izmjeru primjernih stabala divlje trešnje $u$ više gospodarskih jedinica Uprave šuma Podružnice (UŠP) Vinkovci, gdje će se metodom sekcioniranja izmjeriti ukupna nadzemna biomasa stabala uključujući i sitnu granjevinu.

Istraživanje je provedeno na području tri šumarije UŠP Vinkovci (Cerna, Mikanovci i Vinkovci). Ukupno su u tri gospodarske jedinice primjerna stabla divlje trešnje mjerena u 11 odsjeka. U gospodarskoj jedinici (GJ) „Krivsko ostrvo“, ukupne površine 1.488,94 ha u odjelu 31c, starosti 94 godine, omjer smjese drvne zalihe je: hrast lužnjak 86,69 \%, poljski jasen $4,92 \%$, američki jasen $0,34 \%$, obični grab 0,25 $\%$, klen 4,05\%, nizinski brijest $0,85 \%$ i ostale voćkarice 2,90 $\%$. Istraživanje je provedeno na četiri primjerna stabla divlje trešnje. U gospodarskoj jedinici "Muško ostrvo", površine 3.013,68 ha, odjel 18a površine $18,70 \mathrm{ha}$, starosti 60 godina istraživanje je obavljeno na 15 primjernih stabala. 
Omjer smjese drvne zalihe je: hrast lužnjak $32,51 \%$, poljski jasen $42,94 \%$, obični grab $4,02 \%$, klen $14,51 \%$, vez $2,84 \%$ i ostale voćkarice $3,16 \%$.

U gospodarskoj jedinici „Kunjevci“, površine 3.106,43 ha, odjel 10a, površine 43,26 ha, starosti 88 godina obavljeno je istraživanje na 16 primjernih stabala u omjeru smjese drvne zalihe: hrast lužnjak 16,06 \%, poljski jasen 4,75 \%, obični grab $75,78 \%$, klen $2,72 \%$, nizinski brijest $0,21 \%$ i ostale voćkarice $0,46 \%$. U odjelu 11a, starosti 31 godina, istraživanja su provedena na devet primjernih stabala, gdje su ostale voćkarice zastupljene s $0,47 \%$. U odjelu $46 a$, starosti 48 godina, obavljeno je mjerenje na osam primjernih stabala, a ostale voćkarice su zastupljene sa svega $0,38 \%$. U odjelu 51a, starosti 106 godina, ostale su voćkarice zastupljene sa $0,42 \%$, a mjerenje je obavljeno na 10 primjernih stabala. U odjelu 51b, starosti 106 godina izmjerena su dva primjerna stabla divlje trešnje iako se u omjeru smjese vrsta ne navode. U odjelu 54c, starosti 106 godina divlja trešnja zastupljena je sa $1,25 \%$ u omjeru smjese, a istraživanje je obavljeno na 13 primjernih stabala. U odjelu 57b, starosti 126 godina istraživanje je provedeno na tri primjerna stabla. U odjelu 67a, starosti 23 godine, prikupljanje podataka obavljeno je na četiri primjerna stabala. U mlađem odjelu 69 c, starosti 28 godina, površine 33,10 ha istraživanje je obavljeno na 36 primjernih stabala u okviru ostale tvrde bjelogorice (OTB) od 10,00 \%, gdje je evidentirana i divlja trešnja. Ukupno je u navedenim odjelima obrađeno 120 stabala divlje trešnje. U tablici 1 prikazani su objedinjeni podaci po odsjecima za sva primjerna stabla.

\subsection{Metode istraživanja - Research methods}

Terenska istraživanja provedena su na primjernim stablima $\mathrm{u}$ redovitom planu sječa poslovne godine. S obzirom na maleni udio divlje trešnje u redovitim sječama, plan je bio izvršiti izmjeru stabala u svim sječinama, prethodnog i glavog prihoda, u kojima se pojavljuje divlja trešnja. Sječa primjernih stabala obavljena je u razdoblju mirovanja vegeta- cije. Primjerna stabla su mjerena i izrađivana neposredno nakon obaranja (obaranje su izvršili sjekači matične šumarije) ili su obarana, mjerena i izrađivana neposredno prije redovite sječe. Terenska istraživanja obavljao je tim od tri ili četiri osobe, voditelj istraživanja, šumski radnik sjekač i dva pomoćna radnika. Voditelj istraživanja je kao stručna osoba na svim primjernim stablima tijekom terenskih radova vršio prikrajanje i obilježavanje mjesta prereza te je nakon izrade drvnih sortimenata obavljao mjerenje i razvrstavanja prema razredima kakvoće. Nakon završetka sječe, izrade i preuzimanja drvnih sortimenata, obavljena su preostala mjerenja sitne granjevine i uzorkovanja debla i krošnje za laboratorijske analize.

Prsni promjer stabla mjeren je u dubećem ili oborenom stanju (dva međusobno okomita promjera s milimetarskom točnošću). Visina stabla mjerena je nakon obaranja od čela prvoga trupca (pribrajajući visinu panja) do vršnoga pupa, mjernom vrpcom na decimetar točno. Starost stabala određena je brojanjem godova na panju ili debljem kraju prvog trupca uz dodavanje tri godine za srčiku.

Prikrajanje drvnih sortimenata obavljeno je sukladno $\mathrm{Hr}$ vatskim normama proizvoda iskorištavanja šuma iz 1995. godine, vodeći računa da se od raspoloživog drvnog obujma dobije najveća vrijednost. Sukladno standardima određene su sljedeće kategorije za izmjeru: trupci za furnir (F), pilanski trupci I. razreda kakvoće (PT1), pilanski trupci II. razreda kakvoće (PT2), tanka oblovina (TO) i prostorno drvo (PD) koje čine gule i jednometarski ogrjev.

Debljina kore mjerena je pomičnim mjerilom $s$ podjelom na 0,1 milimetar točno, na način da je uzorak kore odvojen od oblog drva sjekirom s dvije suprotne strane ili je na prerezima čela drvnog sortimenta izmjerena debljina kore na oba čela te je za vrijednost debljine korištena njihova aritmetička sredina. Jednometarskom prostornom drvu do 7 $\mathrm{cm}$ promjera je na tanjem kraju također mjerena debljina kore kao i na gulama kraćim od jednog metra.

Tablica 1. Opis uzorka

Table 1. Sample description

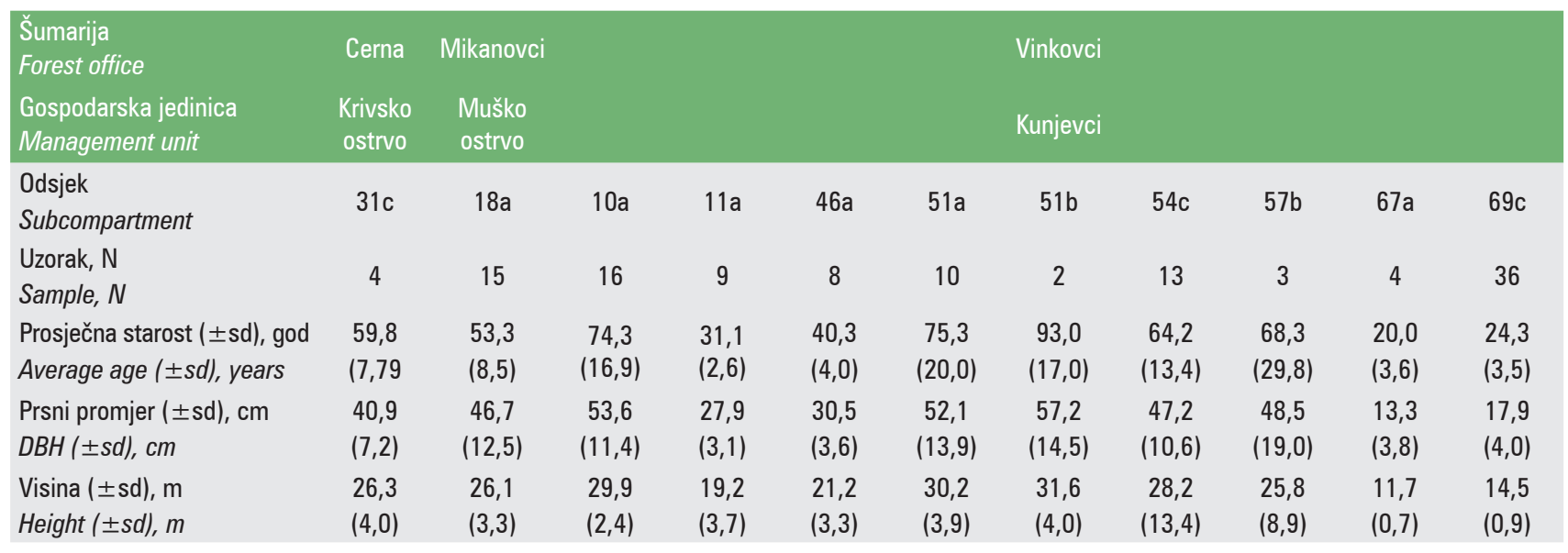


Izrađenoj tehničkoj oblovini i gulama duljina je mjerena na najkraćem mjestu, mjernom vrpcom na centimetar točno, a promjeri (dva međusobno okomita) su mjereni na sredini duljine svakoga sortimenta na milimetar točno. Jednometarskim oblicama promjerkom je na sredini dužine oblice izmjeren jedan promjer na milimetar točno (slika 1).

Uz gubitke uslijed odbitka kore na tehničkoj oblovini i gubitke vezane za normom propisani način izmjere dimenzija, odnosno iskaza obujma, detaljno su evidentirane i sve ostale sastavnice otpada. Stoga je zbrajanjem neto obujma izrađenih sortimenata i evidentiranog obujma sastavnica otpada bilo moguće iskazati bruto obujam krupnog drva pojedinog primjernog stabla. Potom je ovisnost bruto obujma o prsnom promjeru stabla (zaokruženom na centimetar točno) izjednačena Schumacher-Hallovom jednadžbom (Emrović 1960) u cilju određivanja parametara za divlju trešnju i njihove operativne uporabe pri konstrukciji tarifa.

Masa je sitne granjevine tanje od $7 \mathrm{~cm}$ izmjerena po jednom stablu u svakome debljinskom stupnju, odnosno na 13 primjernih stabala. Kod svakoga od tih stabala izvršeno je uhrpavanje grana i izmjera mase dinamometrom svake pojedine hrpe zajedno s korom. Obujam je granjevine izračunat temeljem utvrđene prosječne gustoće u svježem stanju, a njegova je ovisnost o prsnom promjeru stabla izjednačena regresijskom jednadžbom.

Maseni udio vode drva u svježem stanju određen je gravimetrijskom metodom sušenjem uzorka u sušioniku na $105 \pm 2^{\circ} \mathrm{C}$ do postizanja konstante mase. Gustoća drva u svježem stanju određena je kao odnos mase i obujma uzorka neposredno nakon obaranja, a nominalna gustoća je određena kao odnos mase u standardno suhom stanju i obujma u svježem stanju.

Struktura je ukupne nadzemne biomase prikazana uvećavanjem postotnog udjela bruto obujma krupnog drva (po sastavnicama) postotnim iznosom obujma sitne granjevine za pojedini debljinski stupanj.

Regresijskom analizom pokušalo se utvrditi ponašanje udjela pojedinog sortimenta s promjenom prsnog promjera stabla, odnosno ovisnost ta dva parametra. Glavni problem koji se pojavljuje u analizi je postojanje "nepravih“ nula (Vuletić 1999) unutar podataka o kakvoći. „Neprava“ nula je izraz koji se koristi za nepostojanje pojedinog sortimenta u strukturi pojedinog stabla, a koje bi ga prema svojim dimenzijama moglo imati. Primjerice, određeno primjerno stablo promjera $50 \mathrm{~cm}$ nema u svojoj strukturi furnirski sortiment divlje trešnje, a znamo kako se furnirski sortimenti sukladno minimalnim dimenzijama standarda, pojavljuju se od debljinskog stupnja $37,5 \mathrm{~cm}$ na više. Time se stvaraju dva odvojena skupa podataka. Prvi skup predstavljaju izmjereni parovi podataka promjera i udjela pojedinog sortimenta, a drugi skup predstavljaju nule na osi X. Nule predstavljaju stabla određenog promjera koja nemaju u svo-

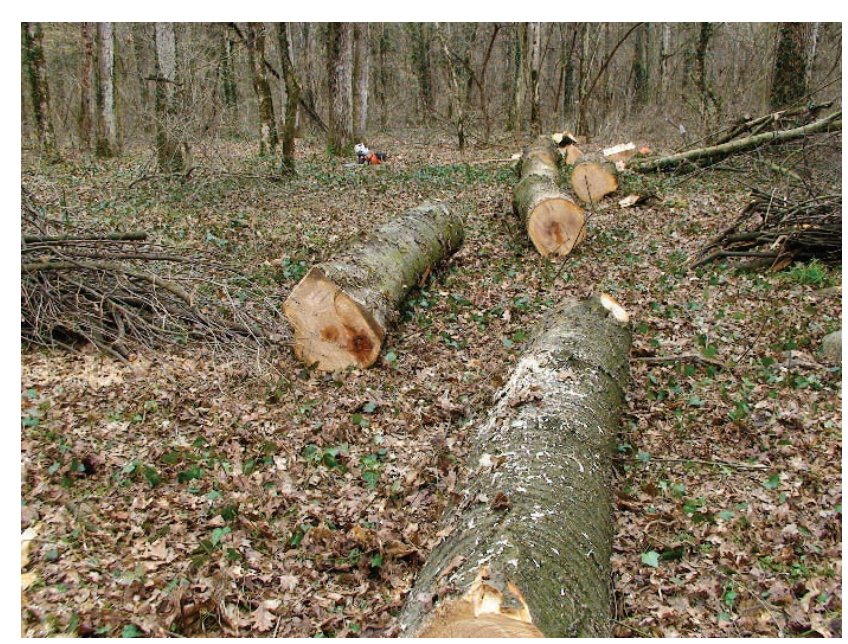

Slika 1. Izrađeni drvni proizvodi divlje trešnje u odjelu 10 A, GJ Kunjevci Figure 1 Bucked wild cherry assortments in subcompartment 10a, management unit Kunjevci

joj strukturi određeni sortiment. To ne znači kako je takvo stablo loše kakvoće, nego samo ne sadrži određeni sortiment. S obzirom na velik varijabilitet nije opravdano postavljati funkciju izjednačenja kroz, na taj način, grupirane podatke. Stoga su primjerna stabla grupirana u debljinske stupnjeve i izračunana je srednja vrijednost udjela pojedinog sortimenata po debljinskom stupnju.

\section{REZULTATI RESULTS}

Istraživanje je provedeno na uzorku od 120 stabala divlje trešnje iz redovitog plana sječa. Prsni promjeri stabala su izmjereni u rasponu od $10 \mathrm{~cm}$ do $72 \mathrm{~cm}$ i razvrstani su u 13 debljinskih stupnjeva širine $5 \mathrm{~cm}$ (slika 2). Utvrđena starost stabala kretala se u rasponu od 16 do 106 godina.

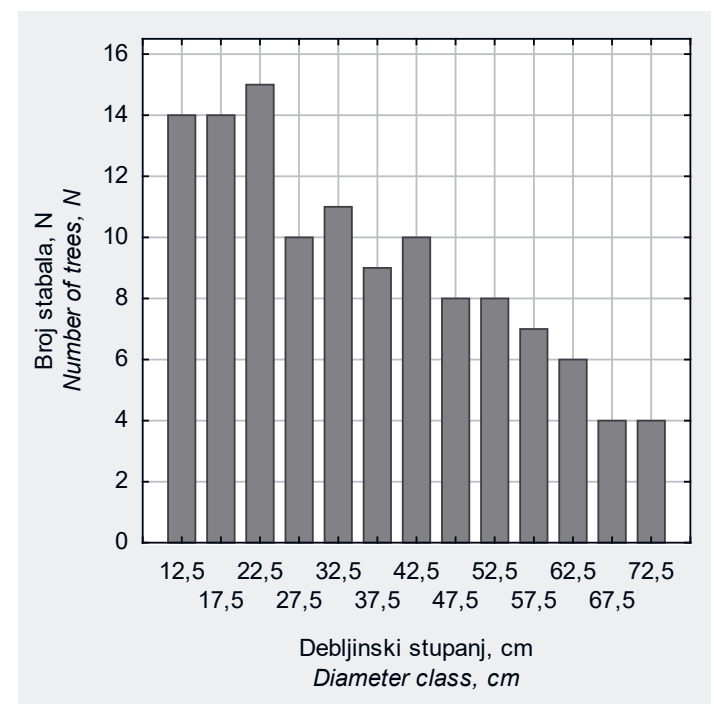

Slika 2. Distribucija broja stabala uzorka po debljinskim stupnjevima Figure 2 Distribution of the number of sample trees by diameter class 
Tablica 2. Statistička značajnost parametara modela obujma,

Table 2. Statistical significance of volume model parameters,

\begin{tabular}{|c|c|c|c|c|c|c|}
\hline \multirow{2}{*}{$\begin{array}{l}\text { Varijabla } \\
\text { Variable }\end{array}$} & \multirow{2}{*}{$\begin{array}{l}\text { Procjena } \\
\text { Estimate }\end{array}$} & \multirow{2}{*}{$\begin{array}{l}\text { Standardna } \\
\text { pogreška } \\
\text { Standard error }\end{array}$} & \multirow{2}{*}{$\begin{array}{c}\text { t-vrijednost } \\
t \text {-value } \\
\mathrm{df}=117\end{array}$} & \multirow{2}{*}{$\begin{array}{l}\mathrm{p} \text {-razina } \\
p \text {-value }\end{array}$} & \multicolumn{2}{|c|}{$\begin{array}{l}\text { Interval pouzdanosti 95,0\% } \\
\text { Conf limit 95.5\% }\end{array}$} \\
\hline & & & & & $\begin{array}{c}\text { Donja granica } \\
\text { Lo. }\end{array}$ & $\begin{array}{c}\text { Gornja granica } \\
\text { Up. }\end{array}$ \\
\hline$b_{0}$ & $-4,49029$ & 0,105879 & $-42,4099$ & $<0,000001$ & $-4,69998$ & $-4,28061$ \\
\hline$b_{1}$ & 2,43205 & 0,048059 & 50,6060 & $<0,000001$ & 2,33687 & 2,52723 \\
\hline$b_{2}$ & 0,56428 & 0,093855 & 6,0122 & $<0,000001$ & 0,37840 & 0,75015 \\
\hline \multicolumn{7}{|c|}{$F(3,117)=7283,70 ; p<0,01$} \\
\hline
\end{tabular}

Aritmetička sredina svih prsnih promjera se nalazi u debljinskom stupnju $37,5 \mathrm{~cm}$, medijan je u debljinskom stupnju $32,5 \mathrm{~cm}$. Visine stabala izmjerene su u rasponu od $10,8 \mathrm{~m}$ do $34,4 \mathrm{~m}$ sa srednjom vrijednošću $22,5 \pm 7,2 \mathrm{~m}$.

\subsection{Parametri Schumacher-Hallove jednadžbe - Parameters of Schumacher-Hall equation}

Izjednačenje ovisnosti obujma krupnog drva o prsnom promjeru i visini stabala provedeno je računskim putem po metodi najmanjih kvadrata uz upotrebu SchumacherHallove jednadžbe (Emrović 1960), a parametri matematičkog modela i njihova statistička značajnost prikazani su u tablici 2.

\subsection{Količina i značajke granjevine - Quantity and features of braches}

Sitna granjevina promjera manjega od $3 \mathrm{~cm}$ ima najveći sadržaj vode i najveću gustoću u svježem stanju nakon obaranja, kao i nominalnu gustoću. Povećanjem promjera grana opada sadržaj vode, kao i gustoća (slike 3 i 4). Gustoća svježe kore je zbog većeg udjela vode veća od istog obujma srži svježeg drva. Padajući trend sadržaja vode i gustoće s povećanjem promjera je zakonitost koja je opće prihvaćena, jer se dvostruka debljina kore povećava s promjerom obloga drva, dok postotni udio dvostruke debljine i obujma kore opada. Prema Krpanu (1986) gustoća kore je veća od gustoće srži drva.

Promjer grana istraživanih uzoraka kretao se $\mathrm{u}$ rasponu od $2,1 \mathrm{~cm}$ do $10,7 \mathrm{~cm}$, sa srednjom vrijednošću $6,09 \pm 2,82 \mathrm{~cm}$. Sadržaj vode izračunat je u rasponu od $33,87 \%$ do $51,18 \%$ sa srednjom vrijednošću $45,63 \pm 3,74 \%$. Kod granjevine tanje od $3 \mathrm{~cm}$ prosječni sadržaj vode je $45,32 \%$, kod grana od 3-7 cm iznosi 45,64\%, a kod grana debljih od $7 \mathrm{~cm}$ iznosi 44,71 \% (slika 3).

Gustoća drva granjevine krošnje u svježem stanju nakon obaranja (slika 4) pokazuje ovisnost o promjeru grana, a kreće se u rasponu od $860 \mathrm{~kg} / \mathrm{m}^{3}$ do $1281 \mathrm{~kg} / \mathrm{m}^{3}$ sa srednjom vrijednošću $1056,87 \pm 92,34 \mathrm{~kg} / \mathrm{m}^{3}$. Vidljivo je opadanje gustoće s porastom promjera grana. Prosječna gustoća drva u svježem stanju sitne granjevine promjera manjeg od $7 \mathrm{~cm}$ iznosi $1058 \mathrm{~kg} / \mathrm{m}^{3}$, a nominalna gustoća iznosi $575 \mathrm{~kg} / \mathrm{m}^{3}$. Gustoća svježeg drva grana promjera većeg od $7 \mathrm{~cm}$ iznosi $1018 \mathrm{~kg} / \mathrm{m}^{3}$, a nominalna gustoća $556 \mathrm{~kg} / \mathrm{m}^{3}$.

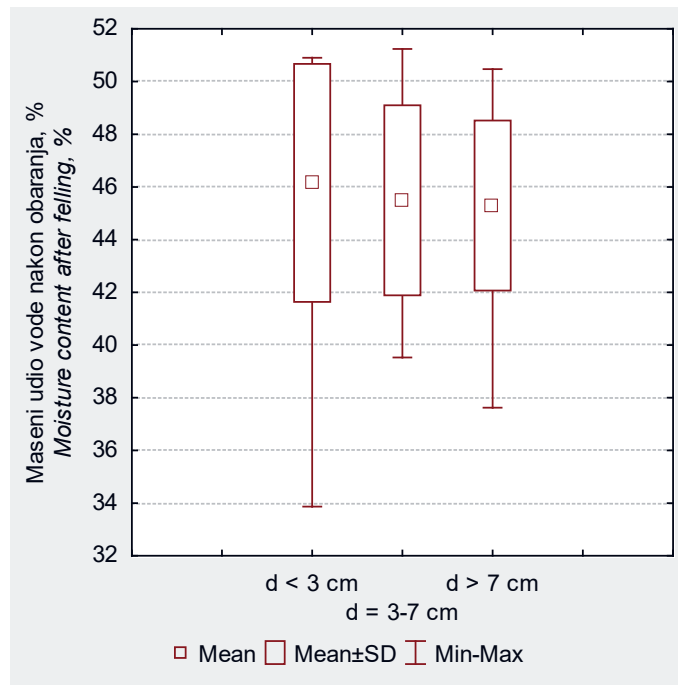

Slika 3. Maseni udio vode u granama nakon obaranja Figure 3 Moisture content in branches after felling

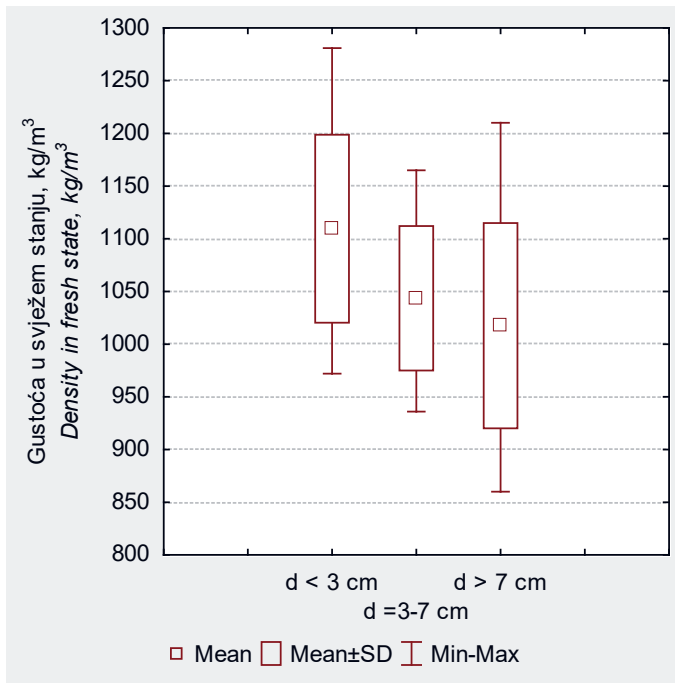

Slika 4. Gustoća drva granjevine u svježem stanju Figure 4 Wood density of branches in fresh state 


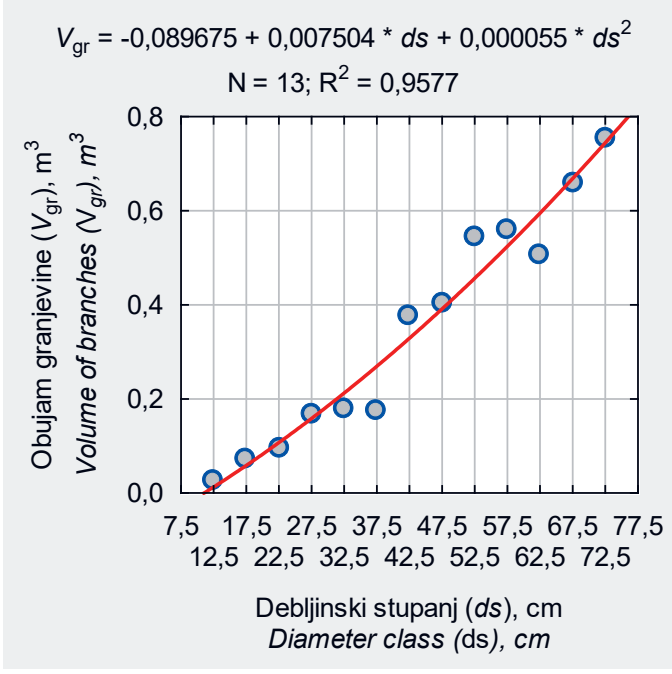

Slika 5. Ovisnost obujma granjevine o debljinskom stupnju Figure 5 Volume of branches vs. diameter class

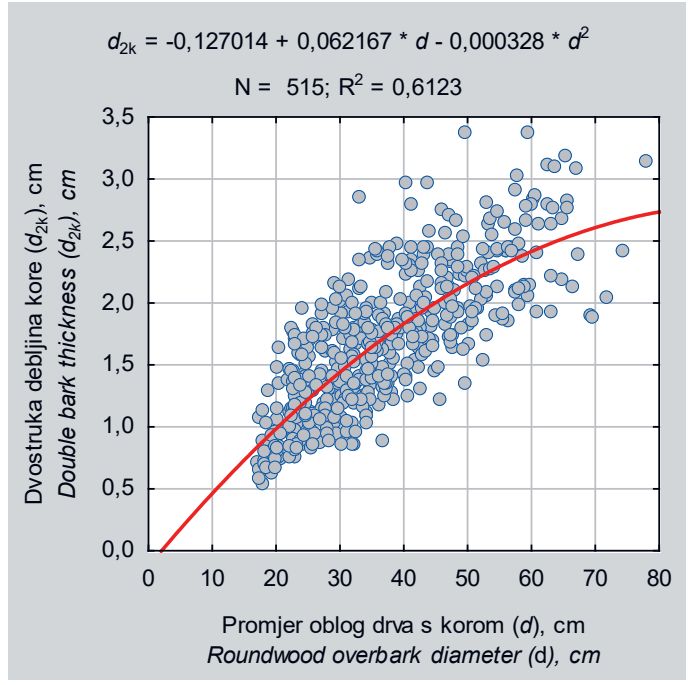

Slika 6. Dvostruka debljina kore u ovisnosti o promjeru oblog drva s korom Figure 6 Double bark thickness vs. roundwood overbark diameter

Tablica 3. Statistička značajnost parametara modela, $d_{2 k}=b_{0}+b_{1} \cdot d+b_{2} \cdot d^{2}$ Table 3. Statistical significance of model parameters, $d_{2 k}=b_{0}+b_{1} \cdot d+b_{2} \cdot d^{2}$

\begin{tabular}{|c|c|c|c|c|c|c|}
\hline \multirow{2}{*}{$\begin{array}{l}\text { Varijabla } \\
\text { Variable }\end{array}$} & \multirow{2}{*}{$\begin{array}{l}\text { Procjena } \\
\text { Estimate }\end{array}$} & \multirow{2}{*}{$\begin{array}{l}\text { Standardna } \\
\text { pogreška } \\
\text { Standard error }\end{array}$} & \multirow{2}{*}{$\begin{array}{l}\text { t-vrijednost } \\
\text { t-value } \\
\text { df }=117\end{array}$} & \multirow{2}{*}{$\begin{array}{l}\mathrm{p} \text {-razina } \\
p \text {-value }\end{array}$} & \multicolumn{2}{|c|}{$\begin{array}{l}\text { Interval pouzdanosti 95,0 \% } \\
\text { Conf limit 95.5\% }\end{array}$} \\
\hline & & & & & $\begin{array}{c}\text { Donja granica } \\
\text { Lo. }\end{array}$ & $\begin{array}{c}\text { Gornja granica } \\
\text { Up. }\end{array}$ \\
\hline$b_{0}$ & $-0,127014$ & 0,138530 & $-0,91687$ & 0,359641 & $-0,399172$ & 0,145143 \\
\hline$b_{1}$ & 0,062167 & 0,007192 & 8,64400 & $<0,000001$ & 0,048038 & 0,076297 \\
\hline$b_{2}$ & $-0,000328$ & 0,000087 & $-3,78434$ & 0,000172 & $-0,000499$ & $-0,000158$ \\
\hline \multicolumn{7}{|c|}{$F(3,512)=4072,49 ; p<0,01$} \\
\hline
\end{tabular}

Masa sitne granjevine kretala se od 27,75 kg za debljinski stupanj $12,5 \mathrm{~cm}$ do $799,75 \mathrm{~kg}$ za debljinski stupanj $72,5 \mathrm{~cm}$, a izjednačenje ovisnosti obujma sitne granjevine (izračunatog na temelju prosječne gustoće u svežem stanju i utvrđene mase) prikazano je na slici 5 .

\subsection{Debljina kore - Bark thickness}

Na svakom izmjerenom sortimentu primjernog stabla izmjerena je i debljina kore. Ukupno je izmjereno 515 podataka dvostruke debljine kore i promjera oblovine. Izmjerene vrijednosti dvostruke debljine kore kretale su se u rasponu od 0,53 cm do 3,37 cm sa srednjom vrijednošću 1,66 $\pm 0,57$ $\mathrm{cm}$. Promjeri na sredini komada oblog drva s kojih su uzimani uzorci izmjereni su u rasponu od $17,2 \mathrm{~cm}$ do $78,1 \mathrm{~cm}$ sa srednjom vrijednošću $36,7 \pm 12,4 \mathrm{~cm}$ (slika 6).

U uzorku se postotni udio kore kretao u rasponu od 4,77 $\%$ do $16,46 \%$, sa srednjom vrijednošću 9,02 $\pm 2,01 \%$. Izjednačenjem postotnog udjela kore u obujmu drvnog sortimenta izračunat je postotni udio kore za debljinski stupanj $22,5 \mathrm{~cm}$ od 9,59\%, a za debljinski stupanj 72,5 cm 7,19\%. Rezultati su potvrdili tezu kako s povećanjem promjera oblovine, postotak dvostruke debljine i obujma kore opada.

\subsection{Sortimentna struktura - Assortment structure}

Ukupno je na 120 primjernih stabala izrađeno 364 komada tehničke oblovine i to: 50 trupaca $\mathrm{F}$ razreda kakvoće, 78 pilanskih trupaca I. razreda kakvoće, 200 pilanskih trupaca II. razreda kakvoće i 36 komada tanke oblovine.

Duljine furnirskih trupaca kretale su se u rasponu od 2,02 $\mathrm{m}$ do $5,07 \mathrm{~m}$ sa srednjom vrijednošću $3,09 \pm 0,80 \mathrm{~m}$. Srednji promjeri trupaca izmjereni su u rasponu od $37,5 \mathrm{~cm}$ do $74,3 \mathrm{~cm}$ sa srednjom vrijednošću $52,08 \pm 9,7 \mathrm{~cm}$. Obujam trupaca kreće se u rasponu od $0,20 \mathrm{~m}^{3}$ do $1,41 \mathrm{~m}^{3}$ sa srednjom vrijednošću $0,61 \pm 0,32 \mathrm{~m}^{3}$. Pilanskim trupcima I. razreda kakvoće duljine izmjerene su u rasponu od 2,00 $\mathrm{m}$ do $5,99 \mathrm{~m}$ sa srednjom vrijednošću $2,95 \pm 0,83 \mathrm{~m}$. Promjeri su izmjereni u rasponu od $27,2 \mathrm{~cm}$ do $63,1 \mathrm{~cm}$ sa srednjom vrijednošću $42,0 \pm 10,4 \mathrm{~cm}$. Obujam se prema normi nalazi u rasponu od $0,11 \mathrm{~m}^{3}$ do $1,20 \mathrm{~m}^{3}$ sa srednjom vrijednošću $0,37 \pm 0,22 \mathrm{~m}^{3}$. Kod pilanskih trupaca II. razreda kakvoće duljine su izmjerene u rasponu od 2,00 $\mathrm{m}$ do $5,46 \mathrm{~m}$ sa srednjom vrijednošću $2,92 \pm 0,75 \mathrm{~m}$. Promjeri se kreću u rasponu od $22,3 \mathrm{~cm}$ do $60,7 \mathrm{~cm}$ sa srednjom vrijednošću 32,1 $\pm 8,8 \mathrm{~cm}$. Obujam je prema normi u rasponu od $0,06 \mathrm{~m}^{3} \mathrm{do}$ $0,87 \mathrm{~m}^{3}$ sa srednjom vrijednošću $0,22 \pm 0,16 \mathrm{~m}^{3}$. Kod drv- 
Tablica 4. Sortimentna struktura krupnog drva divlje trešnje Table 4. Assortment structure of wild cherry wood volume

\begin{tabular}{|c|c|c|c|c|c|c|c|}
\hline $\begin{array}{c}\text { Debljinski } \\
\text { stupanj } \\
\text { Diameter class }\end{array}$ & F - Veneer logs & $\begin{array}{c}\text { PT1 - Saw logs } \\
\text { 1st class }\end{array}$ & $\begin{array}{c}\text { PT2 - Saw logs } \\
\text { 2nd class }\end{array}$ & $\begin{array}{l}\text { T0 - Thin } \\
\text { roundwood }\end{array}$ & $\begin{array}{l}\text { PD - Firewood } \\
\text { and Pulpwood }\end{array}$ & Otpad - Waste & Ukupno - Total \\
\hline $\mathrm{cm}$ & \multicolumn{7}{|c|}{ Obujam \% - Volume, \% } \\
\hline 12,5 & 0,00 & 0,00 & 0,00 & 0,00 & 88,76 & 11,24 & 100,00 \\
\hline 17,5 & 0,00 & 0,00 & 0,00 & 17,44 & 67,44 & 15,12 & 100,00 \\
\hline 22,5 & 0,00 & 0,00 & 17,43 & 15,90 & 47,71 & 18,96 & 100,00 \\
\hline 27,5 & 0,00 & 15,34 & 26,14 & 3,79 & 35,61 & 19,12 & 100,00 \\
\hline 32,5 & 0,00 & 19,89 & 26,89 & 1,56 & 34,78 & 16,89 & 100,00 \\
\hline 37,5 & 9,29 & 14,25 & 21,06 & 1,51 & 37,85 & 16,04 & 100,00 \\
\hline 42,5 & 12,32 & 13,88 & 21,85 & 0,89 & 34,95 & 16,11 & 100,00 \\
\hline 47,5 & 15,01 & 13,63 & 20,25 & 0,38 & 34,84 & 15,89 & 100,00 \\
\hline 52,5 & 15,39 & 12,39 & 22,20 & 0,20 & 33,29 & 16,53 & 100,00 \\
\hline 57,5 & 15,97 & 14,65 & 19,29 & 0,24 & 31,84 & 18,02 & 100,00 \\
\hline 62,5 & 16,02 & 13,02 & 17,30 & 0,00 & 38,38 & 15,27 & 100,00 \\
\hline 67,5 & 19,50 & 15,15 & 21,06 & 0,00 & 27,01 & 17,28 & 100,00 \\
\hline 72,5 & 18,14 & 12,04 & 17,49 & 0,00 & 34,69 & 17,63 & 100,00 \\
\hline
\end{tabular}

nog sortimenta tanka oblovina duljine nalaze se u rasponu od 2,00 $\mathrm{m}$ do 4,24 $\mathrm{m}$ sa srednjom vrijednošću 2,76 $\pm 0,64$ $\mathrm{m}$. Srednji promjeri su izmjereni od $17,2 \mathrm{~cm}$ do $21,9 \mathrm{~cm}$ sa srednjom vrijednošću 19,3 $\pm 1,2 \mathrm{~cm}$. Obujam se prema normi kreće u rasponu od $0,04 \mathrm{~m}^{3}$ do $0,09 \mathrm{~m}^{3}$ sa srednjom vrijednošću $0,06 \pm 0,02 \mathrm{~m}^{3}$.

U tablici 4 prikazana je sortimentna struktura krupnoga drva po debljinskim stupnjevima, a na slici 7 prikazan je sumarni udio tehničke oblovine, udio prostornog drva i udio otpada te sitna granjevina. Udio trupaca za furnir kreće se od 9,29 \% (37,5 cm) do najviše 19,50 \% u debljinskom stupnju $67,5 \mathrm{~cm}$, a prosječno je $15,21 \%$. U zadnjem se debljinskom stupnju $(72,5 \mathrm{~cm})$ smanjuje udio na 18,14 $\%$. Pilanski trupci prvog razreda kakvoće kreću se u rasponu od $12,04 \%(72,5 \mathrm{~cm})$ do $19,89 \%(32,5 \mathrm{~cm})$, a pro- sječno su zastupljeni sa $14,42 \%$. Pilanski trupci drugog razreda kakvoće kreću se u rasponu od 17,30 \% $(62,5 \mathrm{~cm})$ do $26,89 \%(32,5 \mathrm{~cm})$ i prosječno su zastupljeni sa $21,00 \%$. Drvni sortiment tanke oblovine očekivano je najviše zastupljen u debljinskom stupnju $17,5 \mathrm{~cm}$ sa $17,44 \%$ te odmah u sljedećem sa 15,90\%, dok je u višim debljinskim stupnjevima značajno manje. Udio prostornog drva očekivano je najveći u prvom debljinskom stupnju sa $88,76 \%(12,5 \mathrm{~cm})$ te u slijedeća dva sa $67,44 \%$ i $47,71 \%$, a najmanji je u debljinskom stupnju $67,5 \mathrm{~cm}$ sa $27,01 \%$. Prosječni udio prostornoga drva iznosi $42,09 \%$. Otpad se u ukupnoj strukturi krupnog drva kreće od 11,24 $(12,5 \mathrm{~cm})$ do 19,12 \% (27,5 $\mathrm{cm}$ ), a prosječno je zastupljen sa $16,47 \%$ (tablica 4 ).

Prema rezultatima istraživanja i prikaza ukupne nadzemne biomase divlje trešnje (slika 7) tehnička oblovina je zastu-

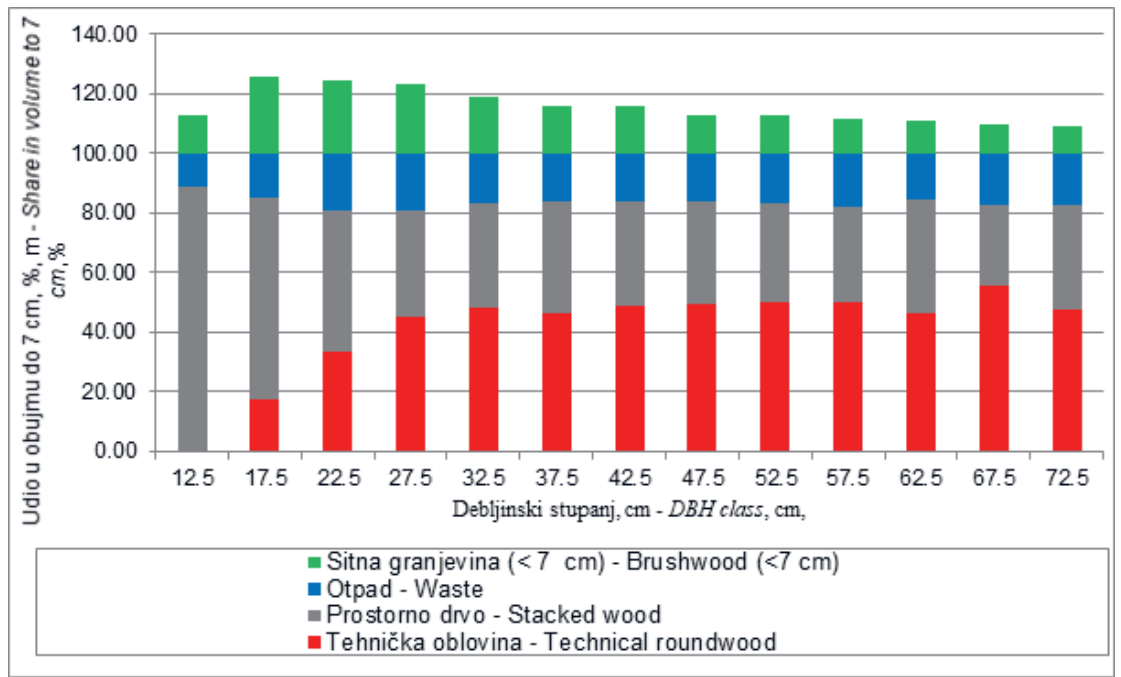

Slika 7. Udjeli drvnih sortimenata i sitne granjevine u obujmu ukupne nadzemne biomase stabala divlje trešnje

Figure 7 Share of timber assortments and branches in total volume of above-ground wild cherry tree biomass 
pljena sa $17,44 \%$ u drugom debljinskom stupnju, zatim sa $33,33 \%$ u trećem debljinskom stupnju, a najviše je zastupljena sa $55,71 \%$ u debljinskom stupnju $67,5 \mathrm{~cm}$. Prostorno drvo je u bruto obujmu stabla očekivano najzastupljenije u prva tri debljinska stupnja i iznosi 88,76\% $(12,5 \mathrm{~cm}), 67,44$ $\%(17,5 \mathrm{~cm})$ i $47,41 \%(22,5 \mathrm{~cm})$, a najmanje je zastupljeno u debljinskom stupnju $67,5 \mathrm{~cm}$ sa $27,01 \%$.

Sitna granjevina tanja od $7 \mathrm{~cm}$ prikazana je kao sastavni dio ukupnog nadzemnog obujma stabala. Uvođenjem novih tehnologija pridobivanja drva, koje uključuju iskorištenje cjelokupne biomase stabala, otvaraju se mogućnosti znatnog povećanja količine proizvodnje iz propisanog etata divlje trešnje. Tako se uključivanjem sitne granjevine u ukupni potencijal drvog obujma povećava količina proizvoda. Nadalje se novim tehnologijama smanjuje i udio otpada, a time se dodatno povećava veće iskorištenje obujma stabala. Sitna granjevina je značajno zastupljena u debljinskom stupnju $17,5 \mathrm{~cm}$ i iznosi $25,5 \%$, a najmanje u debljinskom stupnju $72,5 \mathrm{~cm}$ sa $9,1 \%$, odnosno prosječno iznosi $15,6 \%$ na bruto obujam stabala.

\section{ZAKLJUČAK CONCLUSION}

Precizna i točna informacija o ukupnom drvnom obujmu stabla je ulazni podatak od izrazitog značenja u planiranju i iskorištenju pri sječi stabala i izradi drvnih sortimenata. Različiti izvori i metode izračuna obujma stabala koristili su se prije više desetaka godina i gdjekad rezultiraju značajnim razlikama, kao što je to slučaj kod divlje trešnje.

Utvrđivanje količina nadzemne biomase promjera manjeg od $7 \mathrm{~cm}$ posebno je značajno, jer pri tradicionalnom pridobivanju drva ovaj dio šumskog ostatka najčešće ostaje neiskorišten, a prilikom proizvodnje drvne sječke predstavlja iskoristiv potencijal prihoda naših šuma. Ovaj model može predstavljati podlogu za daljnja istraživanja u cilju poboljšanja planiranja procesa proizvodnje te naknadne analize izvršenih sječa.

Utvrđeno je kako gustoća drva grana ovisi o debljini, odnosno promjeru grana. Gustoća slijedi zakonitost tanjih grana - veća gustoća. Utvrđeno je i kako tanje grane sadrže veći udio vode od deblijh.

Potvrđeno je kako s povećanjem promjera oblovine postotak dvostruke debljine i obujma kore opada. Izjednačene vrijednosti dvostruke debljine kore su manje za sve istraživane promjere oblovine u odnosu na propisane odbitke kore.

Usporedbom udjela sortimenata tehničke oblovine dobivenih istraživanjem i sortimentne tablice koju koriste „Hrvatske šume“ d.o.o. Zagreb, utvrđeno je kako su udjeli furnirskih trupaca i pilanskih trupaca II. razreda kakvoće značajno veći od udjela u sortimentnim tablicama u praktičnoj primjeni, dok je udio pilanskih trupaca I. razreda kakvoće značajno manji.

\section{LITERATURA}

\section{REFERENCES}

- Anon., 1995: Hrvatske norme proizvoda iskorištavanja šuma. II izdanje, Državni zavod za normizaciju i mjeriteljstvo, Zagreb.

- Arač, K., Kranjec Orlović, J., Diminić, D., 2021: Effect of Fungus Meripilus giganteus (Pers.) P. Karst.on Occurrence and Development of False Heartwood and Rot in Fagus sylvatica L. Round Wood. Croatian Journal of Forest Engineering 42(3): 529-542.

- Šumskogospodarska osnova područja Republike Hrvatske od 2016. do 2025. Zagreb 2016. Hrvatske šume d.o.o. Zagreb, str. 1-859.

- Bogdan, S., Kajba, D., Katičić, I., 2006: Produkcija biomase u klonskim testovima stablastih vrba na marginalnim staništima u Hrvatskoj. Glasnik za šumske pokuse, Posebno izdanje 5, Zagreb, 261-275.

- Božić, M., Čavlović, J., Vedriš, M., Jazbec, M., 2007: Modeliranje debljine kore stabala obične jele (Abies alba Mill.). Šumarski list 131 (1-2): 3-12.

- Đuka, A., Sertić, M., Pentek, T., Papa, I., Janeš, D., Poršinsky,T., 2020: Round Wood Waste and Losses - Is Rationalisation in Scaling Possible?. Croatian Journal of Forest Engineering 41(2): 287298.

- Emrović, B., 1960: Dvoulazne tablice drvnih masa za jelu u Gorskom kotaru. Šumarski list 11-12: 345-356.

- Komlenović, N., Krstinić, A., Kajba, D., 1996: Mogućnosti proizvodnje biomase stablastih vrba u kratkim ophodnjama u Hrvatskoj. Unapređenje proizvodnje biomase šumskih ekosustava, Znanstvena knjiga, Hrvatsko šumarsko društvo, Zagreb, 9-21.

- Krpan, A. P. B., 1986: Kora bukve s aspekta eksploatacije šuma. Zbornik radova „Kolokvij o bukvi“ Velika, 22.-24. 11. 1984., Šumarski fakultet Zagreb, 77-88.

- Krpan, A. P. B., Prka, M., Zečić, Ž., 2006: Pojava i značajke neprave srži u bukovim prorednim i oplodnim sječama gospodarske jedinice „Bjelovarska bilogora“. Glasnik za šumske pokuse, Posebno izdanje 5, Zagreb, 529-542.

- Krpan A., Poršinsky T., Zečić Ž., Stankić, I., 2011: Uporabne značajke šumskih kultura alepskog bora (Pinus halepensis Mill.), Utilisation characteristics of Aleppo pine (Pinus halepensis Mill.) forest cultures. Zagreb, Monografija, Šume hrvatskog sredozemlja, str. 670-678. Slavko Matić (ur.).

- Lukić, N., Kružić, T., 1996: Procjena biomase obične bukve (Fagus silvatica L.) u panonskom dijelu Hrvatske. Unapređenje proizvodnje biomase šumskih ekosustava, Znanstvena knjiga, Hrvatsko šumarsko društvo, Zagreb, 131-136.

- Marenče, J., Šega, B., Gornik Bučar, D., 2020: Monitoring the Quality and Quantity of Beechwood from Tree to Sawmill Product. Croatian Journal of Forest Engineering 41(1): 119-128.

- Pavelić, D., 2006: Šumsko-uzgojna svojstva divlje trešnje (Prunus avium L.) s posebnim naglaskom na proizvodnju sjemena i sadnica. Magistarski rad, Šumarski fakultet Sveučilišta u Zagrebu, 1-85.

- Perić, S., 2001: Prvi rezultati o produkciji drvne mase u pokusu provenijencija hrasta lužnjaka (Quercus robur L.) u Hrvatskoj. Znanost u potrajnom gospodarenju hrvatskim šumama, Znanstvena knjiga, Šumarski fakultet \& Šumarski institut \& Hrvatske šume, Zagreb, 223-232.

- Perković, Ž., 2010: Kakvoća bukovih stabala i sortimenata u prebornim šumama Gorskog kotara. Magistarski rad, Šumarski fakultet Sveučilišta u Zagrebu, 1-84. 
- Poršinsky, T., Vujeva J., 2007: Gubici obujma izrađene smrekove oblovine zbog propisanog načina izmjere. Nova mehanizacija šumarstva. Vol. 28: 37-47.

- Poršinsky, T., Petreković, V., Đuka, A., 2020. Debljina kore divlje trešnje pri preuzimanju drva. Šumarski list 144(1-2): 7-14.

- Posarić, D., 2008: Obnova spačvanskih šuma hrasta lužnjaka (Quercus robur L.) oplodnim sječama - mogućnosti poboljšanja postojećeg načina rada. Šumarski list 132 (1-2): 53-63.

- Pranjić, A., Lukić, N., 1997: Izmjera šuma. Udžbenik, Šumarski fakultet Sveučilišta u Zagrebu, 1-405.

- Prka, M., Krpan, A. P. B., 2007: Problem određivanja sortimentne strukture jednodobnih bukovih sastojina. Šumarski list 131 (5-6): 219-235.

- Prka, M., Zečić, Ž., Krpan A. P. B., Vusić, D.: 2009: Characteristics and share of beech false heartwood in felling sites of Central Croatia (Značaj i udio neprave srži bukve u brdskim sječinama središnje Hrvatske). Croatian Journal of Forest Engineering 30(1): 37-49.

- Prka, M., Poršinsky, T., 2009: Usporedba strukture tehničke oblovine jednodobnih bukovih sječina u sortimentnim tablicama izrađenim primjenom normi HRN (1995) i HRN EN 1316-1: 1999. Šumarski list 131(1-2): 15-25.

- Štefančić, A., 1997: Udio drvnih sortimenata u volumenu krupnog drva do $7 \mathrm{~cm}$ promjera za hrast lužnjak, hrast kitnjak i poljski jasen - suši tip. Šumarski list 121 (9-10): 479-497.

- Štefančić, A., 1998: Udio drvnih sortimenata u volumenu krupnog drva do $7 \mathrm{~cm}$ promjera za običnu bukvu u jednodobnim sastojinama. Šumarski list 122 (7-8): 329-337.

- Šušnjar, M., 2001: Neke značajke kakvoće stabala obične jele (Abies alba Mill.) u gospodarskoj jedinici „Belevina“ nastavno-pokusnog šumskog objekta Zalesina. Magistarski rad, Šumarski fakultet Sveučilišta u Zagrebu, 1-157.

- Tikvić, I., Zečić, Ž., Ugarković, D., Posarić, D., 2009.: Oštećenost stabala i kakvoća drvnih sortimenata hrasta lužnjaka na spačvanskom području (Damage of forest trees and quolity of timber assortments of pedunculate oak on spačva area). Šumarski list 133 (5/6): 237 - 248 .

- Vuletić, D., 1999: Prilog poznavanju sortimentne strukture hrasta lužnjaka (Quercus robur L.) u EGT-u II-G-10. Radovi 34 (2), Šumarski institut Jastrebarsko, 5-20.

- Vusić, D., D. Kajba, I. Andrić, I. Gavran, T. Tomić, I. Plišo Vusić, Ž. Zečić, 2019: Biomass Yield and Fuel Properties of Different Poplar SRC Clones. Croatian Journal of Forest Engineering 40(2): 231-238.

- Zečić, Ž., Stankić, I., Vusić, D., Bosner, A., Jakšić, D., 2009: Iskorištenje obujma i vrijednost drvnih sortimentna posušenih stabala jele obične (Abies alba Mill.) (Volume utilization and value of timber assortmets of dried silver fir (Abies alba Mill.) trees). Šumarski list 133 (1/2): 27 - 37.

- Zečić, Ž., Vusić, D., Štimac, Z., Cvekan, M., Šimić, A., 2011: Biomasa nadzemnog dijela stabla obične jele, europskog ariša i crnog bora (Aboveground biomass of silver fir, European larch and black pine). Croatian Journal of Forest Engineering 32 Issue 1, Zagreb, pp. 369 - 377.

- Zečić, Ž., Vusić, D., Franjić, B., 2012.: Biomass potential of common beech (Fagus sylvatica L.) in management unit Zapadni Papuk Zvečevački (Potencijal biomase obične bukve (Fagus sylvatica L.) u gospodarskoj jedinici Zapadni Papuk Zvečevački). Polytechnic of Požega, Proceedings, pp 1139-1147.

- Zečić, Ž., Vusić, D., 2013.: Proizvodni potencijal biomase crnog bora (Pinus nigra Arn.) u šumskim kulturama (Biomass production potential of the black pine (Pinus nigra Arn.) in forestes cultures). HAZU, Znanstveni skup, Šumarstvo i poljoprivreda hrvatskog Sredozemlja na pragu Evropske unije, Zbornik radova, str. 161-174.

- Zelić, J., 2004: Preliminarne sortimentne tablice za hrast sladun (Quercus frainetto Ten). Šumarski list 128 (7-8): 431-443.

\section{SUMIMARY}

The paper presents the structure of the total above-ground biomass of wild cherry (Prunus avium L.) trees in the area of the Spačva basin in the Vinkovci Forest Administration. The research was performed on 120 samples of wild cherry trees with a diameter at breast height (DBH) ranging from 10 to $72 \mathrm{~cm}$ and tree height ranging from 10.8 to $34.4 \mathrm{~m}$. Timber assortments were processed according to the Croatian Standards for Forest Exploitation Products from 1995.

The assortment structure of sample wild cherry trees shows significant deviations in relation to the assortment structure tables used by the company "Croatian Forests" Ltd. Zagreb. The share of veneer logs ranges from $9.29 \%(37.5 \mathrm{~cm})$ to a maximum of $19.50 \%$ in the diameter class of $67.5 \mathrm{~cm}$. Sawmill logs of the first quality class range from $12.04 \%(72.5 \mathrm{~cm})$ to $19.89 \%(32.5 \mathrm{~cm})$, and of the second quality class from $17.30 \%(62.5 \mathrm{~cm})$ to $26,89 \%(32.5 \mathrm{~cm})$. Thin roundwood assortment is represented in the diameter class of $17.5 \mathrm{~cm}$ with $17.44 \%$ and immediately in the next with $15.90 \%$, while in the higher diameter classes it is significantly less represented. The share of stacked wood (firewood and pulpwood) is the highest in the first diameter class, $88.76 \%(12.5 \mathrm{~cm})$ and in the next two with $67.44 \%$ and $47.71 \%$, and is the lowest in the diameter class $67.5 \mathrm{~cm}$ with share of $27.01 \%$. The average share of stacked wood is $42.09 \%$. Waste in the total structure ranges from $11.24(12.5 \mathrm{~cm})$ to $19.12 \%(27.5 \mathrm{~cm})$, and is on average $16.47 \%$. Double bark thickness ranges from $0.53 \mathrm{~cm}$ to $3.37 \mathrm{~cm}$, with an average of $1.66 \pm 0.57 \mathrm{~cm}$, and the percentage of bark share ranges from $4.77 \%$ to $16.46 \%$, with a mean value of $9.02 \pm 2.01 \%$.

The parameters of the Schumacher-Hall equation, wood density, moisture content, branch volume (diameter $<7 \mathrm{~cm}$ ) and the structure of total aboveground biomass were also determined.

KEY WORDS: wood volume, wood assortments, bark thickness, wood waste 